\title{
PENGGUNAAN BUBU LIPAT MODIFIKASI PADA PENANGKAPAN RAJUNGAN (Portunus sp.) DI PERAIRAN UTARA PEMALANG, JAWA TENGAH
}

\author{
Modification Collapsible Pot on Blue Swimming Crab (Portunus sp.) Fisheries in Northern Pemalang \\ Waters, Central Java
}

Oleh:

\author{
Zulkarnain $^{1}$, Ronny Irawan Wahju ${ }^{1}$, Tigor Wahyudi ${ }^{1}$, Fis Purwangka ${ }^{1}$, dan Dwi \\ Putra Yuwandana ${ }^{1}$ \\ ${ }^{1}$ Departemen Pemanfaatan Sumberdaya Perikanan, Fakultas Perikanan dan Ilmu Kelautan, \\ Institut Pertanian Bogor \\ Korespondensi: zulkarnain@apps.ipb.ac.id
}

\begin{abstract}
ABSTRAK
Penelitian ini menggunakan bubu lipat dari hasil modifikasi bubu lipat nelayan yang memiliki dua buah pintu menjadi satu buah pintu (sebagai perlakuan), tetapi memiliki ukuran 4 kali lebih besar dari ukuran bubu nelayan (kontrol). Tujuan penelitian ini adalah membandingkan komposisi hasil tangkapan rajungan, baik jumlah, panjang karapas, dan berat tangkapan, kelayakan tangkap, dan produktivitas antara bubu lipat modifikasi dengan kontrol. Penelitian ini menggunakan 2 perlakuan, 15 pasang bubu lipat pada masing-masing perlakuan, dan 20 kali ulangan (trip). Hasil penelitian menunjukkan bahwa komposisi hasil tangkapan bubu lipat kontrol terdiri dari rajungan (target catch) berjumlah 159 ekor dengan berat 19,1 kg. Hasil tangkapan bubu lipat modifikasi yang terdiri dari rajungan (target catch) 128 ekor dengan berat 15,06 kg. Bubu lipat modifikasi memiliki hasil layak tangkap sebanyak 97\% lebih banyak dari bubu lipat kontrol sebanyak $84 \%$. Hasil uji statistik Uji T menunjukkan hasil tangkapan rajungan tidak memiliki pengaruh nyata dalam berat $(\mathrm{kg})$ tetapi berpengaruh nyata terhadap jumlah individu (ekor). Nilai total produktivitas pada bubu lipat kontrol lebih besar dibandingkan dengan bubu lipat modifikasi.
\end{abstract}

Kata kunci: bubu lipat modifikasi, produktivitas, rajungan

\section{ABSTRACT}

This research uses collapsible pots from the modified of collapsible pots belong local fishermen who have two doors becomes single door (as treatments), but its have measure four times bigger than fisherman's collapsible pot. The aim of this study is to compare the catch composition of blue swimming crab such as the quantity, carapace length and weight, catch worthiness and productivity of modification collapsible pots compare with the fisherman's collapsible pot as a control. This study used 2 treatments, 15 pairs of collapsible pots in each treatment and 20 repetitions. The results showed that the control collapsible pots have caught of blue swimming crab 159 individuals and weighing $19.1 \mathrm{~kg}$, while the modification collapsible pots have 128 individuals and weighing $15.06 \mathrm{~kg}$. Modification collapsible pots have catch worthiness $97 \%$ more catchability compared to $84 \%$ of control collapsible pot. Results of the statistical tests shows that the blue swimming crabs catch have no significant effect in weight $(\mathrm{kg})$ but its have a significant effect on the number (individual). The total value of productivity that control collapsible pot is greater than modification collapsible pot.

Key words: blue swimming crab, modification collapsible pot, productivity 


\section{PENDAHULUAN}

Alat tangkap bubu lipat adalah alat tangkap nelayan yang dioperasikan di perairan pesisir pantai secara pasif untuk memanfaatkan sumberdaya rajungan. Pengoperasian bubu lipat ini mudah dan bersifat pasif, menggunakan umpan yaitu dengan cara menunggu rajungan masuk terperangkap. Saat terperangkap di dalam bubu, rajungan tetap hidup dan dapat bergerak di dalam bubu. Hal ini yang membuat bubu termasuk ke dalam salah satu alat tangkap yang ramah lingkungan. Keberhasilan dalam meningkatkan hasil tangkapan dengan menggunakan bubu dipengaruhi oleh beberapa faktor seperti dimensi ukuran konstruksi bubu (Mallawa dan Sudirman 2004), bahan konstruksi bubu (Komarudin 2012), jenis umpan (Zulkarnain 2012; Purwanto et al 2013), penggunaan umpan (Martasuganda 2003), peletakkan umpan (Miller 1990), letak mulut bubu (Zulkarnain 2012), jumlah mulut dan perendaman bubu (Anung dan Barus 2000). Salah satu bagian terpenting dari bubu lipat adalah bagian mulut bubu (funnel). Bagian tersebut berfungsi sebagai jalan masuk dan sekaligus jebakan bagi setiap organisme yang melewatinya, sedangkan menurut Kurniasih et al. (2016) bahwa desain dan konstruksi bubu lipat dua pintu adalah alat tangkap yang efektif untuk penangkapan dimana bubu dapat memudahkan ikanikan dasar merayap masuk tanpa sengaja dan terperangkap. Salah satu hasil tangkapan bubu adalah rajungan. Menurut Ayodhyoa (1981), Zulkarnain et al. (2011) dan Mukhlish (2012) menjelaskan bahwa berhasilnya suatu penangkapan ikan banyak bergantung kepada pengetahuan mengenai tingkah laku ikan agar dapat menemukan keberadaan ikan.

Rajungan (Portunus sp.) merupakan krustasea yang memiliki habitat alami di laut. Rajungan melakukan migrasi ontogeny karena ada perpindahan habitat yang dilakukan sepanjang metamorphosis daur hidupnya sejak fase telur dilepas ke perairan, hingga menjadi larva, juvenil, dan rajungan dewasa (Kangas 2000). Penelitian ini menggunakan bubu lipat dari hasil modifikasi bubu lipat standar nelayan yang memiliki dua buah pintu. Bubu modifikasi hanya memiliki satu buah pintu yaitu pintu masuk berada di satu sisi bagian depan bubu lipat. Bubu lipat modifikasi satu pintu memiliki ukuran volume empat kali lebih besar dibandingkan bubu lipat nelayan (kontrol). Ukuran bubu lipat modifikasi satu pintu $(60 \mathrm{~cm}$ x $45 \mathrm{~cm} \times 30 \mathrm{~cm}$ ) (Zulkarnain 2012), sedangkan bubu lipat nelayan (kontrol) berukuran $(45 \mathrm{~cm} \times 30 \mathrm{~cm} \times 15 \mathrm{~cm})$.

Perkembangan desain dan konstruksi bubu lipat modifikasi belum banyak dilakukan. Banyak nelayan bubu lipat berasumsi bahwa bubu yang mereka gunakan saat ini cukup efektif karena sistem kerjanya sederhana dan menghasilkan tangkapan rajungan yang banyak. Inovasi teknologi penangkapan bubu lipat memberikan keuntungan yang signifikan (Risamasu, 2008). Bubu lipat modifikasi satu pintu menjadi alternatif alat tangkap lain karena diduga akan mampu memberikan hasil tangkapan rajungan dengan jumlah yang optimal, meskipun harus dilakukan dengan perubahan volume bubu lipat yang lebih besar.

Penelitian sebelumnya telah dilakukan di pesisir selatan pulau Jawa (perairan Teluk Palabuhanratu) dengan dimensi ukuran bubu lipat yang sama yaitu panjang $60 \mathrm{~cm}$, lebar $45 \mathrm{~cm}$, dan tinggi $30 \mathrm{~cm}$. Bentuk mulut bubu yang berbeda dan jumlah pintu masuk berbeda untuk target penangkapan jenis lobster. Maka penelitian kali ini di khususkan di wilayah Pantai Utara Jawa (perairan Kabupaten Pemalang), dimana konstruksi yang digunakan memiliki ukuran yang berbeda berdasarkan dimensinya (empat kali lebih besar) dari ukuran bubu nelayan (kontrol), bentuk mulut pintu berbeda dan jumlah pintu masuk yang berbeda.

Penelitian ini bertujuan untuk membandingkan hasil tangkapan rajungan (Portunus sp.) yaitu komposisi jumlah, panjang karapas, dan berat pada bubu lipat modifikasi dan bubu lipat kontrol, membandingan target hasil tangkapan rajungan (Portunus sp.) bubu lipat modifikasi satu pintu dengan bubu lipat kontrol, dan membandingan kelayaktangkapan bubu lipat modifikasi dengan bubu lipat kontrol terhadap hasil tangkapan rajungan (Portunus sp.), serta membandingkan produktivitas bubu lipat modifikasi dengan bubu lipat kontrol terhadap hasil tangkapan rajungan (Portunus sp.). 


\section{METODE PENELITIAN}

Kegiatan experimental fishing dilakukan pada bulan Februari-Maret 2019 di perairan Pemalang, dimana Pemalang merupakan salah satu pusat aktivitas penangkapan rajungan di pantai utara Jawa Tengah dengan menggunakan alat tangkap bubu lipat.

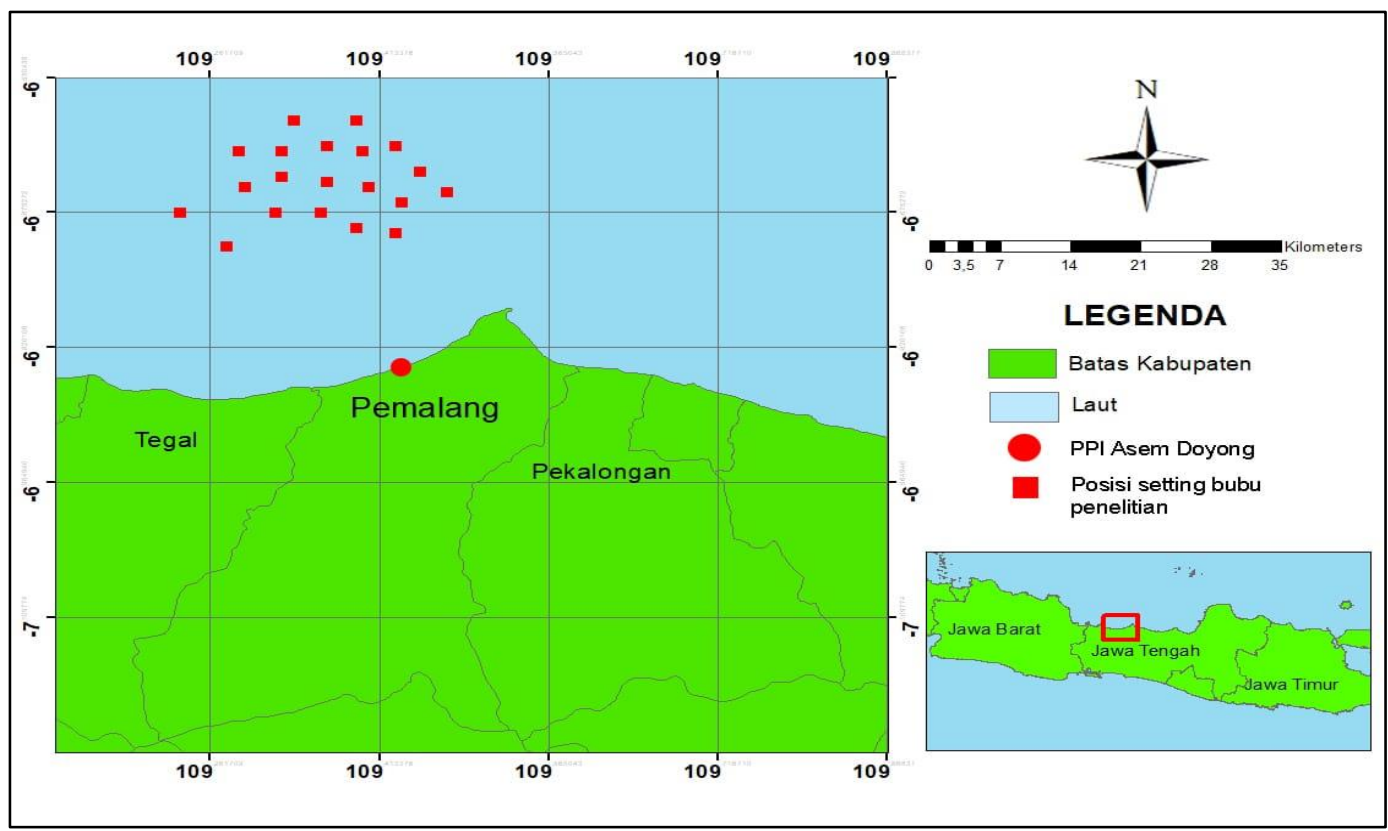

Gambar 1 Peta lokasi penelitian

Alat dan bahan dalam pembuatan bubu lipat modifikasi satu pintu terdiri dari besi galvanis, jaring, benang, tali, dan coban plastik. Sedangkan alat dan bahan yang digunakan pada skala penelitian antara lain perahu, bubu lipat modifikasi satu pintu dan bubu lipat nelayan (kontrol) masing-masing 15 buah, timbangan, kantong plastik bening, alat tulis, dan kamera.

Ukuran bubu lipat kontrol yang digunakan nelayan untuk penangkapan rajungan adalah $45 \mathrm{~cm}$ x $30 \mathrm{~cm}$ x $15 \mathrm{~cm}$. Bubu lipat kontrol dapat dilihat pada Gambar 2.
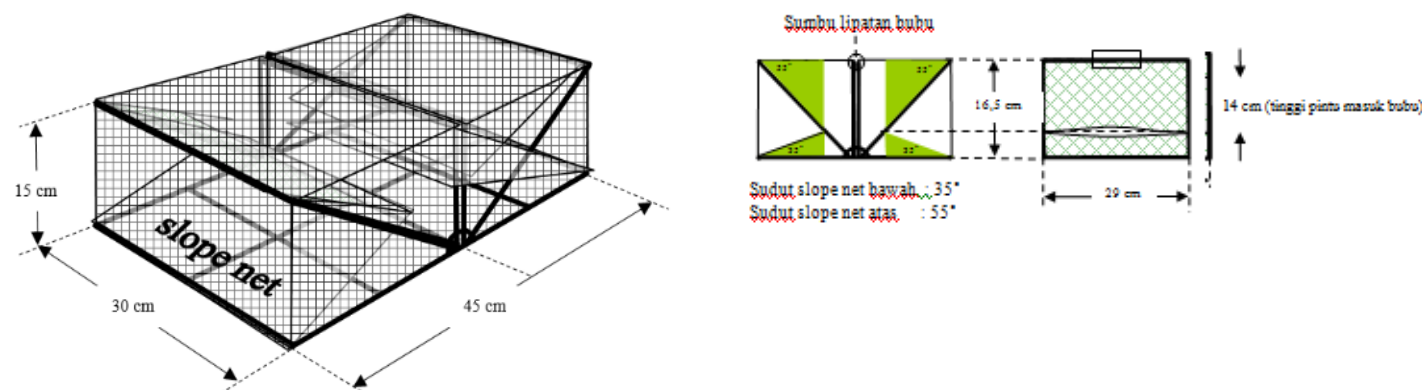

Gambar 2 Desain konstruksi bubu lipat nelayan dua pintu (kontrol). Sumber: Zulkarnain, 2012.

Berdasarkan acuan yang terdapat pada bubu lipat kontrol, maka spesifikasi desain dari bubu lipat modifikasi satu pintu yang digunakan dalam penelitian ini dapat dilihat pada Tabel 1 dan Gambar 3.

Metode pengumpulan data yang digunakan dalam penelitian ini adalah metode experimental fishing yaitu uji coba langsung pengoperasian bubu lipat modifikasi satu pintu di lapangan. Data yang digunakan dalam penelitian ini adalah data primer berupa panjang karapas, panjang ikan, berat ikan, dari hasil kegiatan penangkapan. Data yang dikumpulkan pada pengambilan data tersebut terangkup pada Tabel 2. 
Tabel 1 Spesifikasi alat tangkap bubu lipat modifikasi satu pintu

\begin{tabular}{ll}
\hline Bagian Konstruksi & Spesifikasi \\
\hline Nama & Bubu lipat Modifikasi satu pintu \\
Bentuk Bubu & Persegi panjang (box type) \\
Ukuran Bubu & $60 \mathrm{~cm}$ x $45 \mathrm{~cm}$ x $30 \mathrm{~cm}$ (p x l x t) \\
Jumlah Pintu masuk & 1 pintu, pintu samping \\
Jenis Modifikasi & Ukuran bubu lebih besar 4 (empat) kali dibanding bubu yang \\
& dioperasikan nelayan (kontrol) \\
& Ukuran pintu masuk lebar $14 \mathrm{~cm}$ \\
& Slope net (sudut kemiringan pintu masuk) atas dan bawah : \\
& $22.5^{\circ}$ \\
& Terdapat modifikasi berupa kisi-kisi pada pintu masuk bubu \\
& yang lebih menyulitkan hasil tangkapan untuk lolos \\
Buang dalam bubu lebih besar \\
Badan Jaring (cover net) & Pesi galvanis, diameter 6 mm \\
\hline
\end{tabular}

Sumber: Zulkarnain (2012)
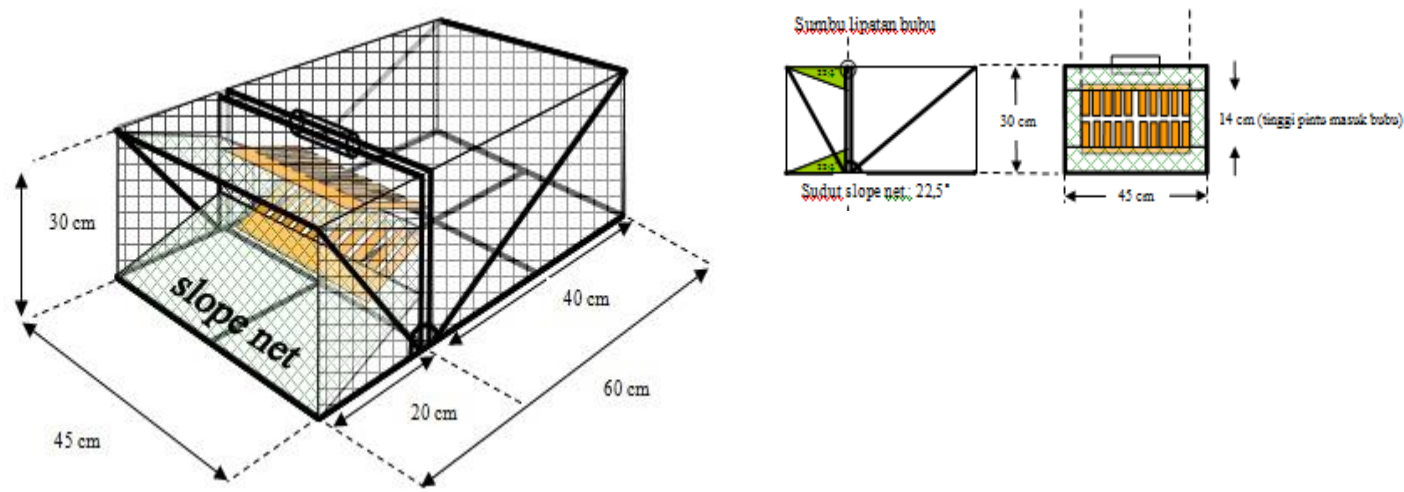

Gambar 3 Desain konstruksi bubu lipat modifikasi satu pintu. Sumber: Zulkarnain, 2012.

Data yang diperoleh terlebih dahulu diuji menggunakan uji normalitas. Metode yang digunakan adalah uji One Sample Kolmogorov-Smirnov (Santoso 2001 dalam Saputra 2017). Setelah data menyebar normal, selanjutnya data diolah dengan menggunakan uji $\mathrm{T}$ (Independent sample t-test) dengan hipotetis: $H O=$ Perbedaan alat tangkap tidak berpengaruh terhadap data hasil tangkapan. $H 1=$ Perbedaan alat tangkap berpengaruh terhadap data hasil tangkapan. Adapun kaidah yang digunakan dalam pengambilan keputusan : jika nilai signifikansi 2 - Tailed > 0,05, maka H0 ditolak dan jika nilai signifikansi 2 - Tailed < 0,05, maka H1 diterima.

Sedangkan data yang tidak menyebar normal dilakukan uji lebih lanjut dengan menggunakan uji non parametrik berupa uji Wilcoxon dengan hipotesis : $\mathrm{H} 0=$ Ada perbedaan antara bubu lipat kontrol dengan bubu lipat modifikasi, dan $\mathrm{H} 1$ = Tidak ada perbedaan antara bubu lipat kontrol dengan bubu lipat modifikasi dua pintu. Adapun kaidah yang digunakan dalam pengambilan keputusan : jika nilai signifikansi 2 - Tailed > 0.05, maka H0 diterima, dan jika nilai signifikansi 2 - Tailed $<0,05$, maka H1 diterima. 
Tabel 2 Metode pengumpulan data

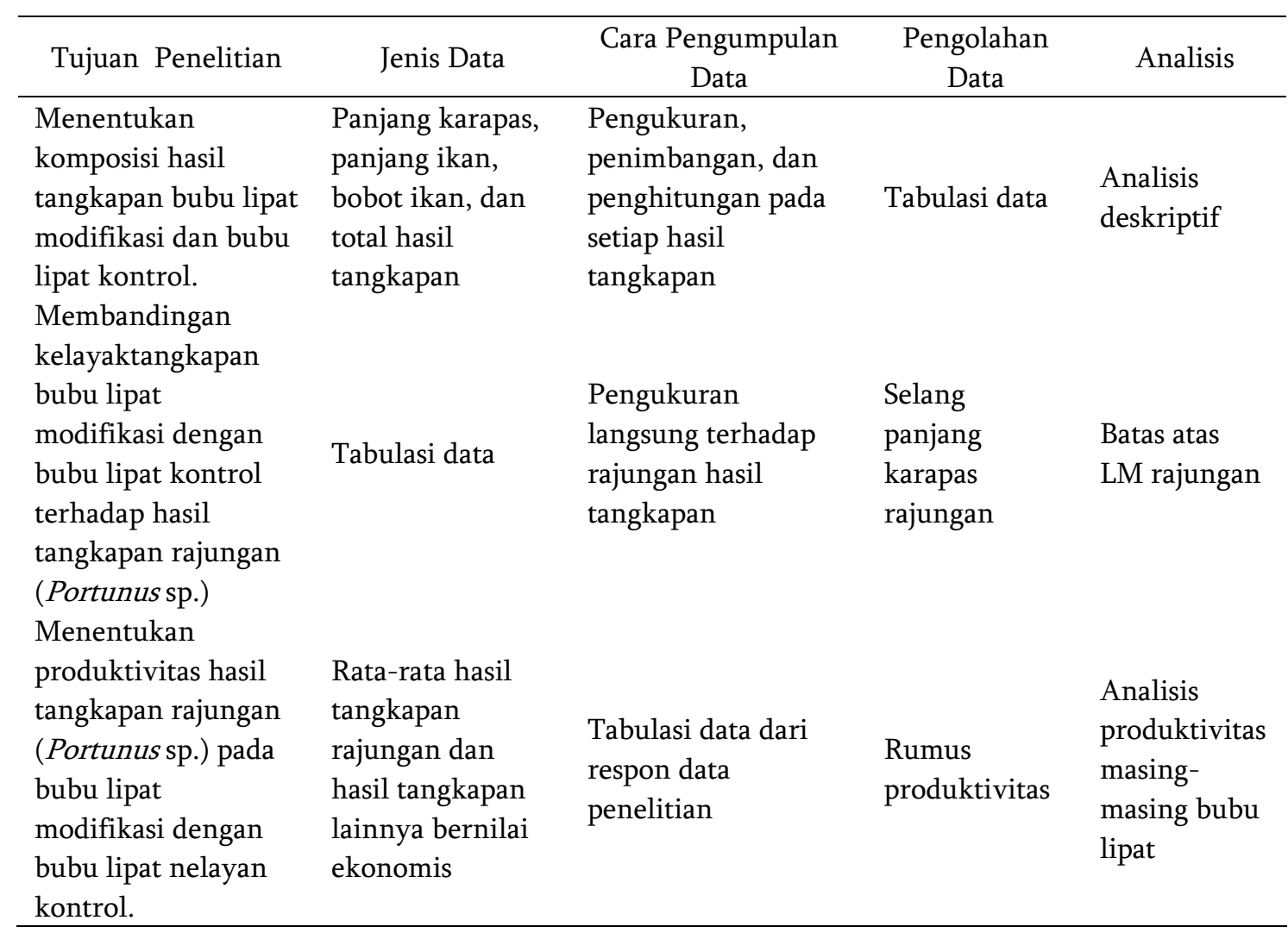

Selain itu perhitungan produktivitas bertujuan untuk melihat kemampuan alat tangkap untuk berproduksi berdasarkan waktu tertentu (Harefa 2019). Metode yang digunakan adalah dengan menghitung nilai produktivitas dengan cara menambah rata-rata tangkapan rajungan dengan rata-rata tangkapan lainnya yang bernilai ekonomis penting pada setiap bubu lipat. Produktivitas dihitung dengan menggunakan rumus (Khair 2007):

\section{Produktivitas bubu $=\bar{R}_{R}+\bar{R}_{L E P}$}

Keterangan:

$\bar{R}_{R} \quad$ = Rata-rata hasil tangkapan rajungan bubu lipat.

$\bar{R}_{\text {LEP }} \quad=$ Rata-rata hasil tangkapan lainnya bernilai ekonomis penting bubu lipat

Nilai rata-rata hasil tangkapan rajungan pada bubu lipat diperoleh dengan menggunakan persamaan:

Total Rajungan

$\overline{\text { total trip } \times \text { total bubu }}$

Sedangkan nilai rata-rata hasil tangkapan lainnya bernilai ekonomis penting pada alat tangkap bubu lipat menggunakan persamaan:

\section{Total HT lainnya ekonomis penting}




\section{HASIL DAN PEMBAHASAN}

Komposisi hasil tangkapan total dalam berat $(\mathrm{kg})$ maupun komposisi hasil tangkapan dalam jumlah (ekor) tercantum dalam Tabel 3 dan Tabel 4.

Tabel 3 Komposisi hasil tangkapan total dalam berat $(\mathrm{kg})$

\begin{tabular}{|c|c|c|c|c|c|c|}
\hline \multirow{3}{*}{ Nama Lokal } & \multirow{3}{*}{ Nama Inggris } & \multirow{3}{*}{$\begin{array}{l}\text { Nama Ilmiah } \\
\text { (Spesies) }\end{array}$} & \multicolumn{4}{|c|}{ Hasil Tangkapan } \\
\hline & & & \multicolumn{2}{|c|}{$\begin{array}{l}\text { Bubu Lipat } \\
\text { Modifikasi }\end{array}$} & \multicolumn{2}{|c|}{$\begin{array}{l}\text { Bubu Lipat } \\
\text { Kontrol }\end{array}$} \\
\hline & & & $\mathrm{Kg}$ & $\%$ & $\mathrm{Kg}$ & $\%$ \\
\hline Rajungan & Blue swimming crab & Portunus sp & 15.06 & 70.09 & 19.10 & 79.55 \\
\hline \multicolumn{2}{|c|}{ Subtotal Target Catch } & & 15.06 & & 19.10 & \\
\hline Kepiting & Mud crab & Scylla sp & 2.61 & 12.12 & 2.01 & 8.37 \\
\hline Udang ronggeng & Squilla mantis & Harpiosquilla $s p$ & 1.27 & 5.91 & 1.71 & 7.12 \\
\hline Kakap merah & Snapper fish & Lutjanus $s p$ & 1.13 & 5.26 & 0.20 & 0.83 \\
\hline Ikan lidah & Flatfish & Cynoglossus sp & 0.11 & 0.51 & 0.00 & 0.00 \\
\hline Bintang laut & Starfish & Asteroidea $s p$ & 0.24 & 1.13 & 0.09 & 0.37 \\
\hline Gurita & Octopus & Octopoda $s p$ & 0.95 & 4.42 & 0.90 & 3.75 \\
\hline Tarantula & Sea spider & Pantopoda sp & 0.12 & 0.56 & 0.00 & 0.00 \\
\hline Subtotal Bycatch & & & 6.43 & & 4.91 & \\
\hline Total & & & 21.49 & & 24.01 & \\
\hline
\end{tabular}

Tabel 4 Komposisi hasil tangkapan total dalam jumlah (ekor)

\begin{tabular}{|c|c|c|c|c|c|c|}
\hline \multirow{3}{*}{ Nama Lokal } & \multirow{3}{*}{ Nama Inggris } & \multirow{3}{*}{$\begin{array}{l}\text { Nama Ilmiah } \\
\text { (Spesies) }\end{array}$} & \multicolumn{4}{|c|}{ Hasil Tangkapan } \\
\hline & & & \multicolumn{2}{|c|}{$\begin{array}{l}\text { Bubu Lipat } \\
\text { Modifikasi }\end{array}$} & \multicolumn{2}{|c|}{$\begin{array}{l}\text { Bubu Lipat } \\
\text { Kontrol } \\
\end{array}$} \\
\hline & & & Ekor & $\%$ & Ekor & $\%$ \\
\hline Rajungan & Blue swimming crab & Portunus sp & 128 & 44.29 & 159 & 57.40 \\
\hline \multicolumn{2}{|c|}{ Subtotal Target Catch } & & 128 & & 159 & \\
\hline Kepiting & Mud crab & Scylla sp & 88 & 30.45 & 71 & 25.63 \\
\hline Udang ronggeng & Squilla mantis & Harpiosquilla sp & 43 & 14.88 & 38 & 13.72 \\
\hline Kakap merah & Snapper fish & Lutjanus sp & 7 & 2.42 & 1 & 0.36 \\
\hline Ikan lidah & Flatfish & Cynoglossus sp & 3 & 1.04 & 0 & 0.00 \\
\hline Bintang laut & Starfish & Asteroidea sp & 17 & 5.88 & 6 & 2.17 \\
\hline Gurita & Octopus & Octopoda sp & 2 & 0.69 & 2 & 0.72 \\
\hline Tarantula & Sea spider & Pantopoda $s p$ & 1 & 0.35 & 0 & 0.00 \\
\hline Subtotal Bycatch & & & 161 & & 118 & \\
\hline Total & & & 289 & & 277 & \\
\hline
\end{tabular}

Komposisi hasil tangkapan total dalam jumlah (ekor) bubu lipat kontrol terdiri dari 6 jenis yaitu rajungan (Portunus sp) 159 ekor (0,574\%), kepiting (Scylla sp) 71 ekor (0,256\%), udang ronggeng (Harspiosquilla sp) 38 ekor (0,137\%), kakap merah (Lutjanus sp) 1 ekor (0,004\%), bintang laut 6 ekor $(0,022 \%)$, dan gurita (Octopus sp) 2 ekor (0,007\%). Komposisi hasil tangkapan total dalam jumlah (ekor) bubu lipat modifikasi terdiri dari 8 jenis. Hasil tangkapan tersebut berupa tangkapan utama (target catch) yaitu rajungan (Portunus sp) 128 ekor (44,29\%). Selain itu, terdapat beberapa hasil tangkapan sampingan (bycatch) antara lain kepiting (Scylla sp) 88 ekor (30,45\%), udang ronggeng (Harspiosquilla $s p) 43$ ekor (14,88\%), kakap merah (Lutjanus sp) 7 ekor (2,24\%), ikan lidah (Cynoglossus sp) 3 ekor (1,04\%), bintang laut 17 ekor (5,88\%), dan gurita (Octopus $s p) 2$ ekor (0,69\%), dan laba-laba laut (Pantopoda sp) 1 ekor (0,35\%). Kedua jumlah hasil tangkapan bubu lipat modifikasi dan bubu lipat kontrol dapat dilihat pada grafik (Gambar 4) 


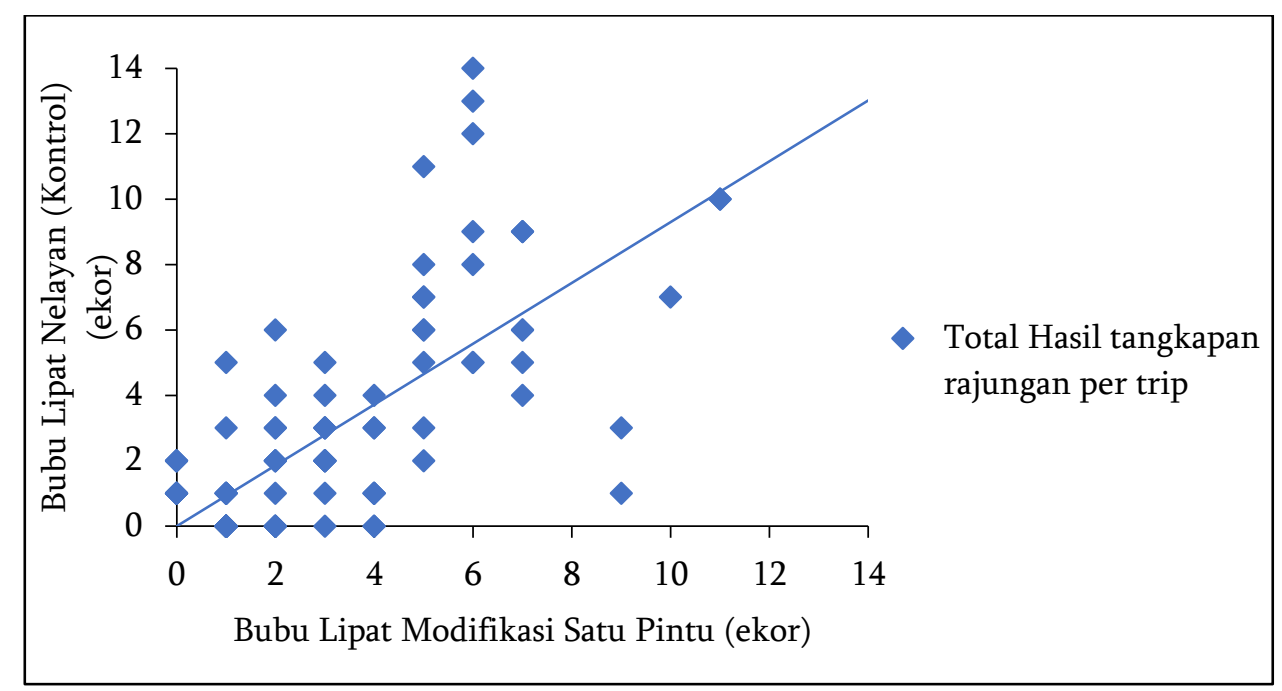

Gambar 4 Jumlah hasil tangkapan total per jenis ikan dalam jumlah (ekor)

Grafik tersebut menjelaskan perbedaan hasil tangkapan dimana titik di atas garis merupakan hasil tangkapan bubu lipat kontrol sedangkan di bawah garis adalah hasil tangkapan bubu lipat modifikasi. Berdasarkan grafik diatas dapat dilihat bahwa bubu lipat kontrol memiliki hasil tangkapan rajungan yang lebih banyak dibandingkan dengan bubu lipat modifikasi. Hal ini terlihat dari titik pada grafik yang dominan berada di atas garis dibandingkan bawah garis.

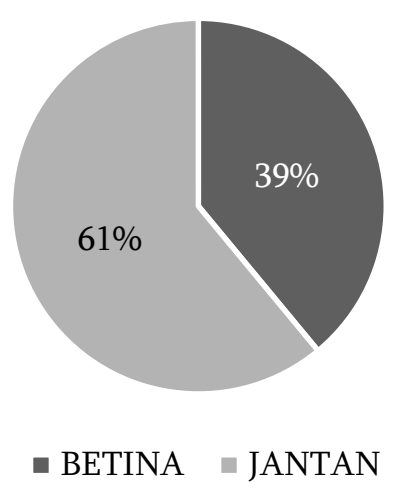

Gambar 5 Komposisi rajungan berdasarkan jenis kelamin pada bubu lipat control

Gambar 5 merupakan perbedaan hasil tangkapan rajungan berdasarkan jenis kelamin pada bubu lipat kontrol. Hasil tersebut dikumpulkan berdasarkan jenis kelamin yang tertangkap dalam semua trip selama pengambilan data. Gambar tersebut menjelaskan bahwa hasil tangkapan rajungan jantan pada bubu lipat nelayan sebesar 61\%, sedangkan rajungan betina sebesar 39\%. Berdasarkan Gambar 6 dapat dilihat bahwa rajungan jantan mendominasi jumlah tangkapan terbanyak dibeberapa selang panjang kelas. Jumlah tangkapan terbanyak rajungan jantan diperoleh pada selang kelas 11,15-12,25 cm dengan tangkapan sebanyak 26 ekor. Hasil tangkapan terbanyak rajungan betina diperoleh pada selang kelas 10,05-11,15 cm dengan jumlah tangkapan sebanyak 20 ekor. 


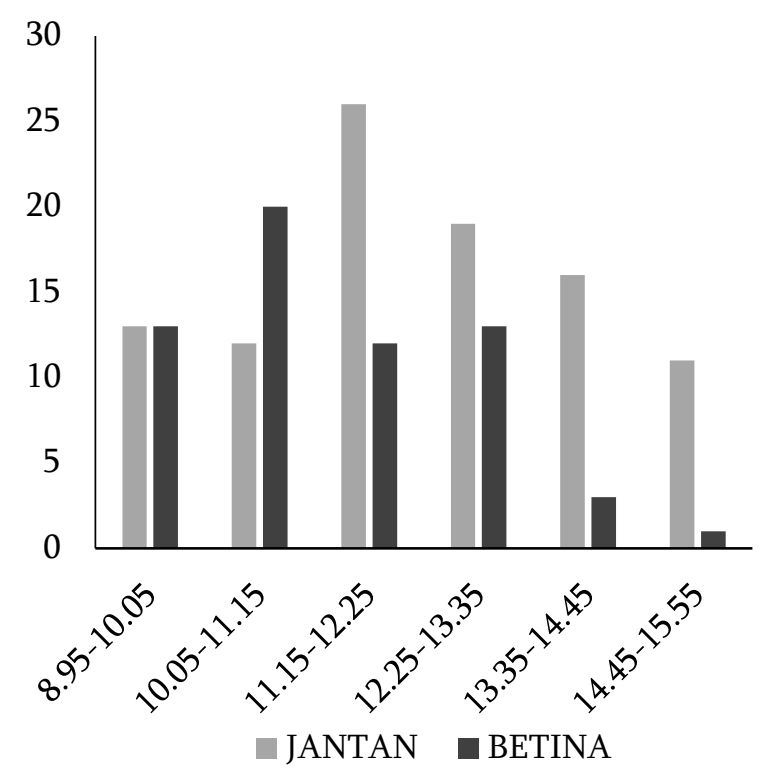

Gambar 6 Sebaran ukuran panjang karapas rajungan jantan dan betina bubu lipat kontrol

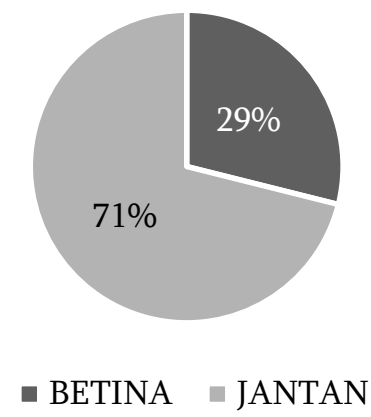

Gambar 7 Komposisi rajungan berdasarkan jenis kelamin pada bubu lipat modifikasi

Gambar 7 merupakan perbedaan hasil tangkapan rajungan berdasarkan jenis kelamin pada bubu lipat modifikasiu. Gambar tersebut menjelaskan bahwa hasil tangkapan rajungan jantan pada bubu lipat modifikasi sebesar $71 \%$, sedangkan rajungan betina sebesar $29 \%$. Hasil tersebut menunjukkan bahwa pada bubu lipat modifikasi, rajungan jantan juga lebih banyak tertangkap dibandingkan dengan rajungan betina. Hasil ini dapat disimpulkan bahwa rajungan jantan merupakan tangkapan terbanyak baik pada bubu lipat modifikasi maupun bubu lipat kontrol. Hal ini dapat terlihat dari perbedaan persentase yang sangat signifikan dari rajungan jantan maupun rajungan betina. Gambar 8 dapat dilihat bahwa rajungan jantan memiliki jumlah tangkapan terbanyak disetiap selang panjang kelas. Jumlah tangkapan terbanyak rajungan jantan diperoleh pada selang kelas 11,15-12,25 cm dengan tangkapan sebanyak 22 ekor. Hasil tangkapan terbanyak rajungan betina diperoleh pada selang kelas 8,95-10,05 $\mathrm{cm}$ dengan jumlah tangkapan sebanyak 11 ekor. Komposisi hasil tangkapan bernilai ekonomis dalam berat $(\mathrm{kg})$ dan jumlah (ekor) dapat dilihat pada Tabel 5 dan Tabel 6. 


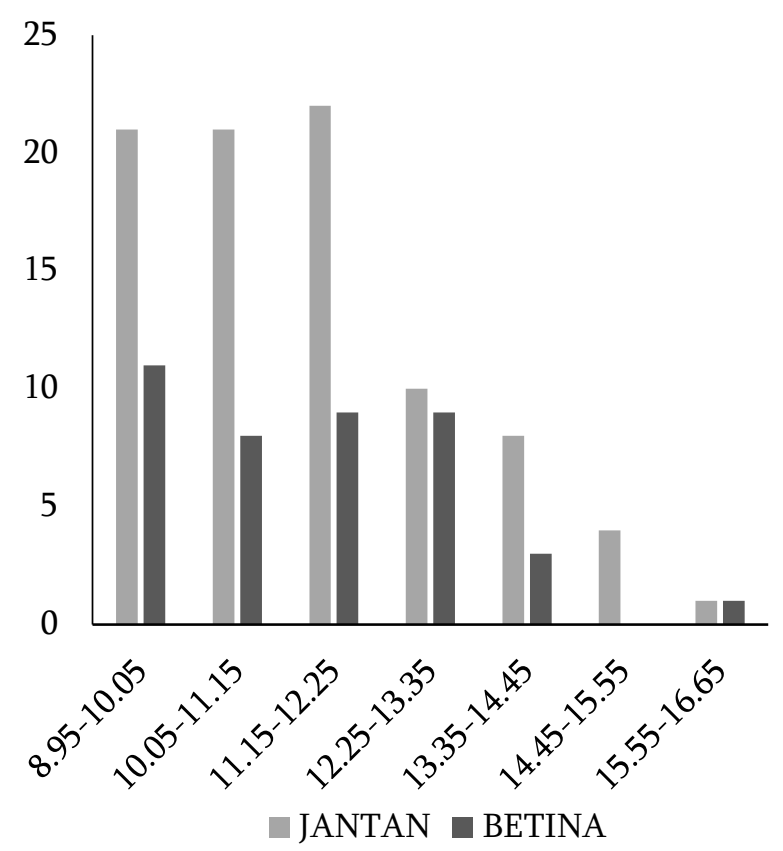

Gambar 8 Sebaran ukuran panjang karapas rajungan jantan dan betina bubu lipat modifikasi Tabel 5 Komposisi hasil tangkapan total ekonomis penting dalam berat (kg)

\begin{tabular}{|c|c|c|c|c|c|c|}
\hline \multirow{3}{*}{ Nama Lokal } & \multirow{3}{*}{ Nama Inggris } & \multirow{3}{*}{$\begin{array}{l}\text { Nama Ilmiah } \\
\text { (Spesies) }\end{array}$} & \multicolumn{4}{|c|}{ Hasil Tangkapan } \\
\hline & & & \multicolumn{2}{|c|}{$\begin{array}{l}\text { Bubu Lipat } \\
\text { Modifikasi }\end{array}$} & \multicolumn{2}{|c|}{$\begin{array}{l}\text { Bubu Lipat } \\
\text { Kontrol }\end{array}$} \\
\hline & & & $\mathrm{Kg}$ & $\%$ & $\mathrm{Kg}$ & $\%$ \\
\hline Rajungan & Blue swimming crab & Portunus sp & 15.06 & 0.82 & 19.1 & 0.87 \\
\hline \multicolumn{2}{|c|}{ Subtotal Target Catch } & & 15.06 & & 19.1 & \\
\hline Udang ronggeng & Squilla mantis & Harpiosquilla sp & 1.27 & 0.07 & 1.71 & 0.08 \\
\hline Kakap merah & Snapper fish & Lutjanus sp & 1.13 & 0.06 & 0.2 & 0.01 \\
\hline Gurita & Octopus & Octopus sp & 0.95 & 0.05 & 0.9 & 0.04 \\
\hline Subtotal Bycatch & & & 3.35 & & 2.81 & \\
\hline Total & & & 18.41 & & 21.91 & \\
\hline
\end{tabular}

Tabel 6 Komposisi hasil tangkapan total ekonomis penting dalam jumlah (ekor)

\begin{tabular}{|c|c|c|c|c|c|c|}
\hline \multirow{3}{*}{ Nama Lokal } & \multirow{3}{*}{ Nama Inggris } & \multirow{3}{*}{$\begin{array}{l}\text { Nama Ilmiah } \\
\text { (Spesies) }\end{array}$} & \multicolumn{4}{|c|}{ Hasil Tangkapan } \\
\hline & & & \multicolumn{2}{|c|}{$\begin{array}{l}\text { Bubu Lipat } \\
\text { Modifikasi } \\
\text { Satu Pintu }\end{array}$} & \multicolumn{2}{|c|}{$\begin{array}{l}\text { Bubu Lipat } \\
\text { Kontrol }\end{array}$} \\
\hline & & & Ekor & $\%$ & Ekor & $\%$ \\
\hline Rajungan & Blue swimming crab & Portunus sp & 128 & 0.71 & 159 & 0.80 \\
\hline \multicolumn{2}{|c|}{ Subtotal Main Catch } & & 128 & & 159 & \\
\hline Udang ronggeng & Squilla mantis & Harpiosquilla sp & 43 & 0.24 & 38 & 0.19 \\
\hline Kakap merah & Snapper fish & Lutjanus sp & 7 & 0.04 & 1 & 0.01 \\
\hline Gurita & Octopus & Octopus sp & 2 & 0.01 & 2 & 0.01 \\
\hline \multicolumn{2}{|l|}{ Subtotal Bycatch } & & 52 & & 41 & \\
\hline \multicolumn{2}{|l|}{ Total } & & 180 & & 200 & \\
\hline
\end{tabular}


Tabel 7 Sebaran hasil tangkapan berdasarkan layak dan tidak layak tangkap

\begin{tabular}{lll}
\hline \multicolumn{1}{c}{ Jenis Bubu } & \multicolumn{1}{c}{ Layak Tangkap } & \multicolumn{1}{c}{ Tidak Layak Tangkap } \\
\hline Bubu Lipat Modifikasi & Rajungan 97\% & Rajungan 3\% \\
& & Kakap 100\% \\
Bubu Lipat Kontrol & Rajungan 84\% & Ranjungan 16\% \\
& & Kakap 100\% \\
\hline
\end{tabular}

Tabel 7 menjelaskan sebaran data hasil tangkapan berdasarkan length of maturity pada setiap bubu lipat. Berdasarkan tabel tersebut dapat dilihat bahwa bubu lipat modifikasi memiliki hasil tangkapan layak tangkap sebanyak 97\%, sedangkan bubu lipat kontrol sebesar 84\%. Hal ini dapat diartikan bahwa bubu lipat modifikasi memiliki nilai layak tangkap terbanyak dibandingkan dengan bubu lipat modifikasi kontrol.

Berdasarkan hasil uji kenormalan data menggunakan One Sample Kolmogorov-smirnov yang dilakukan pada komposisi hasil tangkapan total rajungan dalam berat $(\mathrm{kg})$ dan hasil tangkapan total rajungan dalam jumlah (ekor) menyebar normal. Hasil output uji T terhadap komposisi hasil tangkapan rajungan dalam berat $(\mathrm{kg})$ pada selang kepercayaan 95\% ( $\mathrm{P}>0,05)$ dan hasil output uji T hasil tangkapan dalam jumlah (ekor) $(\mathrm{P}>0,05 \%)$ adalah significant, sehingga dapat diartikan perbedaan antara bubu lipat kontrol dengan bubu lipat modifikasi berpengaruh terhadap hasil tangkapan total rajungan. Hasil tersebut dapat pula diartikan total hasil tangkapan rajungan dalam berat (kg) maupun dalam jumlah (ekor) pada bubu lipat kontrol lebih besar dibandingkan bubu lipat modifikasi. Perbandingan rata-rata hasil tangkapan total rajungan dalam berat $(\mathrm{kg}) \pm \mathrm{SE}$ dapat dilihat pada Gambar 9.

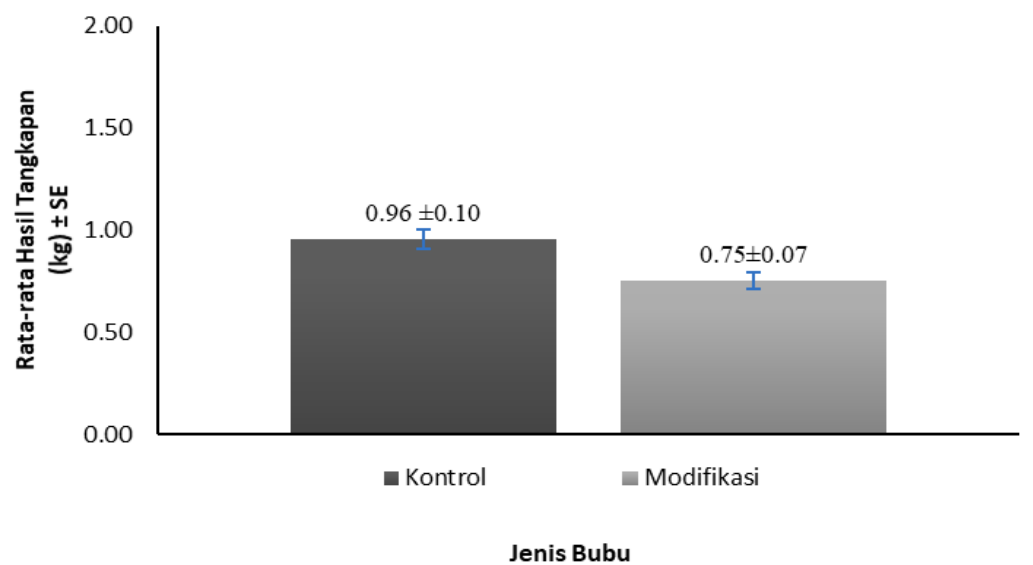

Gambar 9 Rata-rata hasil tangkapan rajungan dalam berat $(\mathrm{kg}) \pm \mathrm{SE}$

Berdasarkan hasil uji kenormalan data tangkapan bernilai ekonomis dalam berat (kg) dan jumlah (ekor) menggunakan uji One Sample Kolmogorov-smirnov, komposisi hasil tangkapan bubu lipat bernilai ekonomis menyebar normal dan berdasarkan hasil pengujian menggunakan uji $\mathrm{T}$ dengan selang kepercayaan 95\% ( $>>0,05)$ menunjukkan bahwa perbedaan konstruksi pada bubu lipat adalah significant. Hasil tersebut dapat diartikan perbedaan bubu lipat kontrol dengan bubu lipat nelayan modifikasi berpengaruh terhadap hasil tangkapan yang bernilai ekonomis. Hasil tangkapan bernilai ekonomis dalam berat (kg) maupun dalam jumlah (ekor) pada bubu lipat modifikasi lebih kecil dibandingkan dengan bubu lipat kontrol. Perbandingan rata-rata hasil tangkapan bernilai ekonomis dalam berat $(\mathrm{kg}) \pm \mathrm{SE}$ dapat dilihat pada Gambar 10 . 


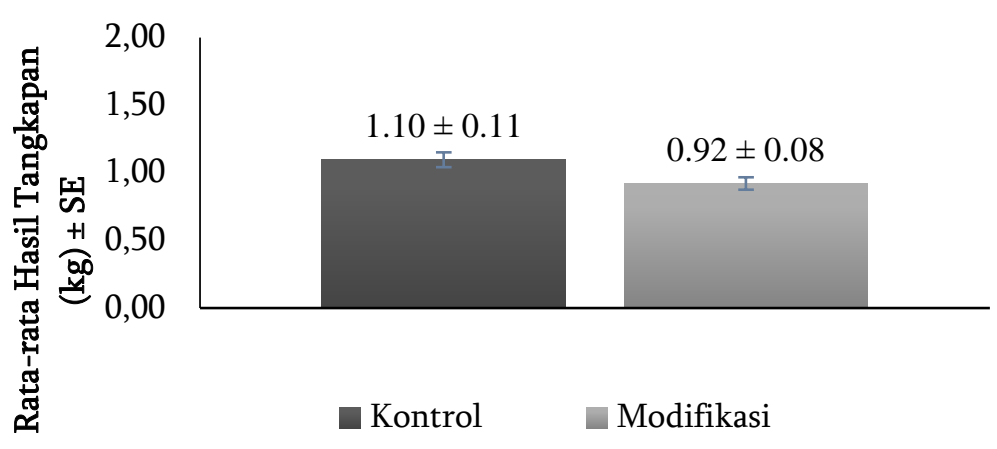

Jenis Bubu

Gambar 10 Rata-rata hasil tangkapan bernilai ekonomis dalam berat $(\mathrm{kg}) \pm \mathrm{SE}$

Berdasarkan hasil uji coba penangkapan rajungan pada bubu lipat kontrol dan bubu lipat modifikasi, produktivitas hasil tangkapan rajungan pada pengoperasian penangkapan ikan dapat dilihat pada Tabel 8.

Tabel 8 Produktivitas hasil tangkapan pada bubu lipat (kg/bubu/trip)

\begin{tabular}{llll}
\multicolumn{1}{c}{ Jenis Alat Tangkap } & Rajungan & $\begin{array}{c}\text { Ikan ekonomis } \\
\text { penting }\end{array}$ & Total \\
\hline Bubu Lipat Kontrol & 0,050 & 0,064 & 0,114 \\
Bubu Lipat Modifikasi & 0,011 & 0,009 & 0,020 \\
\hline
\end{tabular}

Dari tabel di atas dapat disimpulkan bahwa bubu lipat kontrol memiliki nilai produktivitas yang tinggi yaitu 0,114 kg/bubu/trip, sedangkan bubu lipat modifikasi memiliki nilai produktivitas 0,020 $\mathrm{kg} / \mathrm{bubu} /$ trip. Hasil tersebut dapat disimpulkan setiap bubu lipat kontrol dapat menangkap rajungan sebanyak 0,050 kg/bubu/trip dan $0,064 \mathrm{~kg} / \mathrm{bubu} /$ trip ikan ekonomis penting lainnya pada setiap kegiatan penangkapan. Sedangkan bubu lipat modifikasi satu pintu dapat menangkap sebanyak 0,011 $\mathrm{kg} / \mathrm{bubu} /$ trip rajungan dan 0,009 $\mathrm{kg} / \mathrm{bubu} /$ trip ikan ekonomis penting lainnya pada setiap kegiatan penangkapan.

Bubu lipat merupakan salah satu jenis alat tangkap yang digunakan nelayan yang ada di Kabupaten Pemalang. Bubu lipat adalah alat penangkap ikan yang banyak digunakan oleh nelayan tradisional untuk menangkap rajungan, udang, ikan demersal, ikan karang, ikan hias, ikan terbang dan lain-lain. Selain digunakan di laut, bubu dapat juga digunakan di perairan umum (Wibyosatoto 1994). Bubu lipat modifikasi satu pintu merupakan bubu lipat dengan penambahan pintu jebakan bentuk kisikisi bahan plastik. Penambahan kisi plastik pada pintu masuk bubu dapat memudahkan ikan masuk ke dalam bubu dan sulit meloloskan diri (Zulkarnain 2012). Bubu lipat modifikasi satu pintu memiliki konstruksi yang empat kali lebih besar $(60 \mathrm{~cm} \mathrm{x} 45 \mathrm{~cm} \mathrm{x} 30 \mathrm{~cm}$ ) dibandingkan dengan bubu lipat nelayan (kontrol) (45 x $30 \mathrm{cmx} 15 \mathrm{~cm}$ ). Perbedaan ukuran dimensi pada bubu lipat dilakukan untuk meningkatkan hasil tangkapan dengan target penangkapan jenis rajungan. Selain itu, bentuk pintu masuk pada bubu lipat modifikasi satu pintu berbentuk persegi panjang (box type) dilengkapi dengan pintu pemicu (trigger) sedangkan pada bubu lipat nelayan berbentuk ellips atau slit type. Pintu pemicu (trigger) merupakan pintu masuk yang memicu hasil tangkapan untuk masuk ke dalam bubu dan mencegah terjadinya pelolosan. Penggunaan pintu pemicu pada pintu sangat efektif untuk pencegahan pelolosan rajungan dari bubu, selama tidak menghalangi target spesies untuk masuk ke dalam bubu (Salthaug 2002 dalam Zulkarnain 2012)

Berdasarkan hasil experimental fishing terdapat 8 jenis hasil tangkapan terdiri dari rajungan (Portunus pelagicus), kepiting (Scylla sp), udang ronggeng (Harpiosquilla raphidea), kakap merah (Lutjanus sp), gurita (Octopus sp), bintang laut (Asteroidae sp), dan laba-laba laut (Pantopodae sp). 
Berdasarkan hasil tangkapan tersebut terdapat 4 dari 8 jenis hasil tangkapan yang merupakan tangkapa bernilai ekonomis yaitu rajungan (Portunus pelagicus), udang ronggeng (Harpiosquilla raphidea), kakap merah (Lutjanus sp), dan gurita (Octopus sp). Hasil tangkapan keseluruhan bubu lipat modifikasi yaitu sebesar 289 ekor lebih banyak dibandingkan dengan bubu lipat kontrol (277 ekor). Rajungan merupakan hasil tangkapan terbanyak baik pada bubu lipat kontrol maupun bubu lipat modifikasi.

Produktivitas bubu lipat merupakan produksi bubu lipat setiap kali pengoperasian. Produktivitas hasil tangkapan pada bubu lipat terdiri dari bubu lipat kontrol dan bubu lipat modifikasi. Berdasarkan hasil perhitungan, nilai total produktivitas pada bubu lipat kontrol sebesar 0,114 (kg/bubu/trip) lebih besar dibandingkan dengan bubu lipat modifikasi yaitu sebesar 0,020 (kg/bubu/trip). Hal ini disebabkan karena adanya biota selain rajungan dan ikan ekonomis lainnya seperti ikan lidah, laba-laba laut, dan bintang laut yang mudah masuk kedalam bubu lipat modifikasi. Penyebab dari rendahnya hasil tangkapan pada bubu lipat modifikasi terletak pada lamanya waktu penggunaan bubu. Menurut Utami (2019) dalam hasil wawancara dengan nelayan, rendahnya jumlah hasil tangkapan dapat dipengaruhi oleh lamanya penggunaan bubu. Semakin sering bubu digunakan maka biota akan semakin banyak biota seperti lumut, telur cumi-cumi, dan biota lainnya yang menempel pada bubu lipat. Hal tersebut membuat rajungan tertarik untuk masuk ke dalam bubu dan akan mempengaruhi hasil tangkapan pada saat operasi penangkapan. Penelitian sebelumnya tentang perbandingan efektivitas bubu lipat modifikasi yang telah dilakukan pada ukuran dimensi yang sama dengan jenis umpan berbeda pada penangkapan lobster di perairan selatan pulau Jawa (Mukhlish 2012). Penelitian tersebut menyimpulkan bahwa hasil tangkapan yang didapat oleh semua jenis bubu lipat didominasi oleh hasil tangkapan sampingan, dimana hasil tangkapan sampingan tersebut didominasi oleh spesies rajungan. Hal ini mengindikasikan bahwa rajungan tersebut juga tertarik untuk masuk kedalam bubu lipat kontrol maupun bubu lipat modifikasi. Hasil tangkapan yang sedikit dari bubu lipat modifikasi disebabkan oleh kisi-kisi pada mulut bubu yang sedikit menghambat rajungan untuk masuk. Menurut Mukhlish (2012) keberadaan kisi-kisi pada mulut bubu mengganggu proses masuknya hasil tangkapan sehingga menyulitkan bagi ikan untuk masuk, hal tersebut dikarenakan jari-jari pada kisi-kisi tersebut terlalu panjang untuk melangkah dan menerobos masuk untuk mengejar umpan.

\section{KESIMPULAN DAN SARAN}

Komposisi hasil tangkapan rajungan pada bubu lipat kontrol berjumlah 159 ekor $(19,10 \mathrm{~kg})$ dan hasil tangkapan bubu lipat modifikasi 128 ekor $(15,06 \mathrm{~kg})$. Penggunaan bubu lipat modifikasi tidak memiliki pengaruh nyata terhadap komposisi total hasil tangkapan rajungan dan komposisi total hasil tangkapan bernilai ekonomis baik dalam berat $(\mathrm{kg})$ maupun jumlah (ekor). Bubu lipat modifikasi memiliki hasil layak tangkap sebanyak $97 \%$ lebih banyak dari bubu lipat kontrol sebanyak $84 \%$. Nilai total produktivitas untuk setiap 15 bubu lipat, yaitu pada bubu lipat kontrol (0,96 kg/trip) lebih besar dibandingkan dengan bubu lipat modifikasi (0,75 kg/trip).

Sebelum bubu digunakan dalam penelitian, sebaiknya dilakukan proses perendaman di air laut dalam jangka waktu tertentu.

\section{DAFTAR PUSTAKA}

Anung A. dan Barus HA. 2000. Pengaruh Jumlah Mulut, Jenis Umpan dan Lama Perendaman Bubu Terhadap Hasil Tangkapan Ikan Demersal di Selat Sunda. Prosiding Seminar Hasil Penelitian Perikanan 1999/2000.Pusat Penelitian dan Pengembangan Eksplorasi Laut dan Perikanan. Jakarta. Hal133-139.

Ayodhyoa AU. 1881. Metode Penangkapan Ikan. Yayasan Dewi Sri. Bogor.

Harefa BJ. 2019. Uji Coba Rumpon Portable Terhadap Hasil Tangkapan Gillnet Dasar di Teluk Banten Kabupaten Serang [skripsi]. Bogor (ID): Institut Pertanian Bogor. 
Kangas MI. 2000. Synopsis of the biology and exploitation of the blue swimmer crab, Portunus pelagicus Linnaeus, in Western Australia. Fisheries Research Report 121.

Khair MPBR. 2007. Preferensi Hasil Tangkapan Dogol Di Desa Karangreja, Kecamatan Suranenggala, Kabupaten Cirebon [Skripsi]. Bogor (ID): Institut Pertanian Bogor.

Komarudin D. 2012. Rancang Bangun Bubu Lipat Untuk Menangkap Kepiting Bakau (Scylla serrata). [thesis]. Bogor (ID): Institut Pertanian Bogor.

Kurniasih A, Ririn I, Adi S. 2016. Efektifitas Celah Pelolosan Pada Bubu Lipat Terhadap Hasil Tangkapan Rajungan di Teluk Banten. Jurnal Perikanan dan Kelautan. Vol. 6 No. 2 : 95-103hlm.

Mallawa A dan Sudirman. 2004. Teknik Penangkapan Ikan. Jakarta (ID): Reneka Cipta.

Martasuganda S. 2003. Bubu (Trap). Bogor (ID) : Institut Pertanian Bogor

Miller RJ. 1990. Effectiveness of Crab and Lobster Traps. Canadian Journal of Fisheries and Aquatic Science. Ottawa(CA): 47(4): 1228-1251.

Mukhlish. 2012. Efektivitas Bubu Lipat Modifikasi Dengan Jenis Umpan Berbeda pada Penangkapan Lobster Di Perairan Palabuhanratu [skripsi]. Bogor (ID): Institut Pertanian Bogor.

Purwanto, Akir A, Arsti DPF, Bambang AW. 2013. Perbedaan umpan terhadap hasil tangkapan udang galah (Macrobracrium idea) alat tangkap bubu bambu (ICIR) di Perairan Rawapening. Fisheries Resources Utilization Management and Technology. 3(2):72-81.

Risamasu FJL. 2008. Inovasi teknologi penangkapan ikan karang dengan bubu dasar berumpon. [disertasi]. Bogor (ID): Institut Pertanian Bogor. 39-178.

Salthaug A. 2002. Do Triggers in Crab Trap Affect the Probability of Entry? Fisheries Research. Elsevier B.V. All right reserved. Volume 58: 403-405p.

Saputra DO. 2017. Penggunaan umpan wak-wak (Xenosiphon $s p$ ) pada pancing ulur yang dioperasikan siang hari di Kecamatan Manggar Pulau Belitung [skripsi]. Bogor (ID): Institut Pertanian Bogor.

Utami WD. 2019. Penggunaan Dua Pintu Pada Konstruksi Mulut Bubu Lipat Modifikasi [skripsi]. Bogor (ID): Institut Pertanian Bogor.

Zulkarnain. 2012. Rancang Bangun Bubu Lipat Modifikasi dan Penggunaan Cacing Tanah (Lumbricus rubellus) sebagai umpan alternatif untuk penangkapan Spiny lobster [disertasi]. Bogor (ID): Institut Pertanian Bogor.

Zulkarnain, Baskoro MS, Martasuganda S, Monintja DR. 2011. Pengembangan desain bubu lobster yang efektif. Buletin PSP. 16(2):45-47.

Zulkarnain, Baskoro MS, Martasuganda S, Monintja DR. 2011. Efektivitas bubu lipat modifikasi dan penggunaan umpan cacing tanah (Lumbricus rubellus) pada penangkapan spiny lobster (Panulirus spp.) di perairan pesisir timur Teluk Palabuhanratu Jawa Barat. Buletin PSP. 16(3):239-252. 